STUDY OF ANCIENT DOLOMITIC MORTARS OF THE CHURCH OF SANTA

MARÍA DE ZAMARCE IN NAVARRA (SPAIN). COMPARISON WITH SIMULATED STANDARDS

C. Montoya, J. Lanas, M. Arandigoyen, I. Navarro, P.J. García Casado, J.I. Alvarez*

Department of Chemistry and Soil Science, University of Navarra, 31080 Pamplona, Spain.

$\mathbf{N}^{0}$ of pages: 31

$\mathbf{N}^{\circ}$ of tables: 5

$N^{0}$ of figures: 6

Please, send all correspondence to:

Dr. José I. Alvarez-Galindo

Dpto. de Química y Edafología

Fac. de Ciencias

Universidad de Navarra

$\mathrm{C} /$ Irunlarrea $\mathrm{s} / \mathrm{n}$

31080 Pamplona (Navarra)

Spain

Phone: 34948425600

Fax: 34948425649

E-mail: jalvarez@unav.es 


\title{
STUDY OF ANCIENT DOLOMITIC MORTARS OF THE CHURCH OF SANTA MARÍA DE ZAMARCE IN NAVARRA (SPAIN). COMPARISON WITH SIMULATED STANDARDS
}

\author{
C. Montoya, J. Lanas, M. Arandigoyen, I. Navarro, P.J. García Casado, J.I. Alvarez* \\ Department of Chemistry and Soil Science, University of Navarra, 31080 Pamplona, Spain.
}

\begin{abstract}
Ten ancient mortars from the church of Santa María de Zamarce (Navarra, Spain) have been studied by means of chemical analysis, X-ray diffraction and simultaneous thermogravimetric and differential thermal analysis (TGA-DTA). All of the studied samples have shown to be dolomitic mortars. Sixteen simulated standards of typically present compounds in dolomitic mortars were prepared and studied. Particularly the occurrence of hydrated magnesium carbonate hydroxide (hydromagnesite, $\left.\mathrm{Mg}_{5}\left(\mathrm{CO}_{3}\right)_{4}(\mathrm{OH})_{2} \cdot 4 \mathrm{H}_{2} \mathrm{O}\right)$ as result of the setting of dolomitic mortars is discussed. No hydromagnesite has been checked in mortars from Santa María de Zamarce. However, TGA-DTA studies have clearly shown the thermal decomposition of hydromagnesite in the prepared mixtures, specially the exothermic peak at $500^{\circ} \mathrm{C}$. The experimental conditions in TGA-DTA, with a high $\mathrm{CO}_{2}$ pressure around the sample, seem to play an important role in the occurrence of this phenomenon. Suitable experimental conditions for thermal studies of these materials have been indicated.
\end{abstract}

Keywords: Dolomitic mortars; Thermal analysis; Hydromagnesite; Self-generated atmosphere; X-ray diffraction 


\section{Introduction and Objectives}

The knowledge of the chemical composition of the mortars used in the construction of historical-artistic monuments has an enormous interest. Now, the restorations carried out on this type of constructions often use similar materials to the original ones in composition and properties, according to the conclusions of the Symposium "Mortars, Cements and Grouts used in the Conservation of Historic Buildings" [1]. Rodríguez-Navarro et al. [2] state the advantages related to the use of lime mortars instead of Portland cements in the restorations: in addition to historic and aesthetic reasons, lime mortars do not release soluble salts and they are more chemically, structurally and mechanically compatible with much ancient masonry.

In general, lime mortar is the most widely used in historical-artistic constructions. To this type of mortar and its composition and properties have been dedicated numerous works of research: Franzini et al. [3] have studied lime mortars from some medieval buildings in Pisa and they have proposed a method for determining the chemical composition of binder and aggregate; Frizot [4] and Gutiérrez-Solana et al. [5] have analysed the chemical and mineralogicalpetrographical compositions from ancient lime mortars.

Mortars with a dolomitic lime are less abundant than the aforementioned mortars. Nevertheless, the study of the variations of their behaviour, the characteristics of the present phases and the methods of determination of the same ones have an undeniable scientific interest. Certain discrepancies in the specialised literature have also motivated this work. The controversy is about the occurrence of phases originated during the setting of this type of mortars (for example hydromagnesite, HY): whereas Bruni et al. [6] and Dheilly et al. [7] have indicated that the carbonation of a dolomitic lime (that is, containing magnesium hydroxide - brucite, $\left.\mathrm{Mg}(\mathrm{OH})_{2}\right)$ can originate usually hydromagnesite, and Vecchio et al. [8] have determined the presence of HY in Italian dolomitic mortars $\left(11^{\text {th }}\right.$ and $14^{\text {th }}$ centuries $)$, Newton and Sharp [9] have only found magnesite and brucite in some dolomitic mortars and Alessandrini et al. [10] have not determined hydromagnesite in the binder fraction from some dolomitic mortars. Botha 
and Strydom [11] state as conclusion in their work that HY only can be prepared from magnesium hydroxide if the experimental conditions are chosen carefully (and with a $\mathrm{CO}_{2}$ flow of $190 \mathrm{~mL} \mathrm{~min}^{-1}$ ). Also the work by Dheilly et al. [7] has shown HY obtained after curing in a $\mathrm{CO}_{2}$ atmosphere, and Caceres and Attiogbe [12] have produced $\mathrm{HY}$ after recarbonation of $\mathrm{Mg}(\mathrm{OH})_{2}$ - from calcined dolomite - in a $\mathrm{CO}_{2}$ excess.

The advisable analytical techniques to characterise dolomitic binding materials (and also the information which is provided by these techniques) is also matter of controversy: Vecchio et al. [8] have determined HY by means of XRD and DTA-TGA, but unexpectedly they have not observed the exothermic peak at $500^{\circ} \mathrm{C}$; however, Bruni et al. [13] state the difficulty in determine HY by using XRD due to the poor crystallinity of the HY, and also, the conditions for the occurrence of the exothermic peak in the thermal decomposition of HY have been presented in the work by Sawada et al. [14] and in a recent paper by Khan et al. [15].

In order to define the composition and to characterise the type of binder employed, ten ancient mortars of dolomitic origin, used in the building of the church of Santa María de Zamarce (1141-1167), have been studied. The church is in the rural Romanesque style of Navarra (Spain), with a single nave of three sections with semicircular apse (Fig. 1) [16].

In a previous work by the research group a methodology for characterisation of the mortars have been detailed [16]. In the present paper, the results obtained by means of chemical analysis, $\mathrm{X}$ ray diffraction $(\mathrm{XRD})$ and simultaneous differential thermal and thermogravimetric analysis (TGA-DTA), are offered.

Considering the references of the literature and the experimental results, sixteen different patterns from phases that could be present in materials of these characteristics have been prepared. The objectives are: to clarify the possibilities of occurrence of these phases in mortars, as well as the suitability of the use of the XRD and the TGA-DTA in their determination. Experimental conditions that allow the occurrence of the exothermic peak and the set of phenomena of HY thermal decomposition have been settled down. 
This work shows the type of mortars used in the church of Santa María de Zamarce, as well as the comparative study between the bibliographical data and the simulated standards of these materials. The obtained results confirm the complementary use of XRD and thermal studies for the adequate characterisation of these binding materials.

\section{Experimental}

The sampling procedure for binding materials has been carried out taking a part of the mortars with a chisel and throwing away the external portion of the joints, with the aim of obtaining non-altered material. Figure 1 shows the sampling points.

The sample, ground in an agate mortar, was dried in a heater at $105^{\circ} \mathrm{C}$ until constant weight and then $1 \mathrm{~g}$ of sample was taken for its subsequent chemical analysis.

The chemical analysis of the main components has been carried out by attack with a sodium carbonate-borax alkaline flux, and afterwards by traditional chemical procedures [16]: a titration with ethylenediaminetetraacetic acid (EDTA) (using murexide and eBT (eriochrome black $\mathrm{T}$ ) as indicators) in order to determine calcium and magnesium concentrations; sodium and potassium levels were determined by flame atomic emission spectroscopy (Perkin Elmer 460, Überlingen, Germany); $\mathrm{R}_{2} \mathrm{O}_{3}$ ( $\mathrm{Fe}, \mathrm{Al}$ and $\mathrm{Ti}$ oxides) was determined by gravimetry (precipitation in the solution and calcination); sulphates $\left(\mathrm{SO}_{3}\right)$ were evaluated by precipitation as $\mathrm{BaSO}_{4}$ with a $10 \% \mathrm{w} / \mathrm{w} \mathrm{BaCl}_{2}$ solution; $\mathrm{SiO}_{2}$ was determined by weight difference of the sample (final-initial weight) after treatment in platinum crucible with HF (40\% w/w) and a few drops of $\mathrm{H}_{2} \mathrm{SO}_{4}$.

The mineralogical phases contained in the samples were determined by means of XRD, that was undertaken using a Bruker D8 Advance diffractometer (Karlsruhe, Germany), according to the diffraction powder method, with a $\mathrm{CuK}_{\alpha 1}$ radiation and 0.02 increment and $1 \mathrm{~s} / \mathrm{step}$, sweep 2 to $90,2 \theta /^{\circ}$. 
The differential thermal and thermogravimetric analysis were carried out using a simultaneous TGA-sDTA 851 Mettler Toledo (Schwerzenbach, Switzerland) thermoanalyser, using alumina crucibles, with holed lids, at $20^{\circ} \mathrm{C} \min ^{-1}$ heating rate, under static air atmosphere, from ambient temperature to $1050^{\circ} \mathrm{C}$.

The standard mixtures were prepared using chemical reagents that figure next:

- C (Calcite): $\mathrm{CaCO}_{3}$ calcium carbonate PA Merck Ref. 2066

- Q (Quartz): $\mathrm{SiO}_{2}$ silicon dioxide from sea sand washed QP Panreac Ref. 1214

- P (Portlandite): $\mathrm{Ca}(\mathrm{OH})_{2}$ calcium hydroxide PA Merck Ref. 2047

- $\mathrm{MgO}$ (Periclase): MgO magnesium oxide PA Merck Ref. 5865

- $\mathrm{HY}$ (Hydromagnesite): $\mathrm{Mg}_{5}\left(\mathrm{CO}_{3}\right)_{4}(\mathrm{OH})_{2} \cdot 4 \mathrm{H}_{2} \mathrm{O}$ hydrated magnesium carbonate hydroxide PA Merck Ref. 5827

Simulated standards were prepared according to weight ratios indicated: pure HY; HY+C (1:1); $\mathrm{HY}+\mathrm{C}(1: 2) ; \mathrm{HY}+\mathrm{C}(1: 3) ; \mathrm{HY}+\mathrm{C}(1: 4) ; \mathrm{HY}+\mathrm{C}(1: 5) ; \mathrm{HY}+\mathrm{C}+\mathrm{Q}(1: 1: 1) ; \mathrm{HY}+\mathrm{C}+\mathrm{Q}(1: 6: 12)$ HY+Q (1:1); HY+Q (1:2); HY+P (1:1); HY+P (1:2); HY+P+Q (1:6:12); HY+MgO (1:1); $\mathrm{HY}+\mathrm{MgO}(1: 2) ; \mathrm{HY}+\mathrm{MgO}(2: 1)$. After weighing the required amounts of the components, they were intimately mixed in an agate mortar, and they were transferred to sealed glass containers in order to avoid hydrations and carbonations.

\section{Results and discussion}

\subsection{Study of Santa María de Zamarce ancient mortars}

\subsubsection{Chemical and XRD studies}

Table 1 shows the results of the chemical analysis of the samples of mortars of Santa María de Zamarce. Table 2 shows the results of X-ray diffraction patterns (XRD) of the same samples. Main components of these samples are: calcium carbonate as crystalline phase of calcite (calcium oxide and calcination loss, in the chemical analysis), silicon dioxide as $\alpha$-quartz, and 
calcium and magnesium carbonate (oxides of calcium and magnesium and calcination loss, in the chemical analysis), that appears identified as dolomite in XRD pattern.

Z1 and Z2 samples of Santa María de Zamarce present significant amounts of gypsum (calcium sulphate dihydrate) in the study by XRD. Chemical analysis confirms this presence, with a sulphate $\left(\mathrm{SO}_{3}\right)$ content of $1.44 \%$ and $6.52 \%$ respectively. Other phases as bassanite $\left[\mathrm{CaSO}_{4}\right.$ $0.5 \mathrm{H}_{2} \mathrm{O}$ ICDD 41-0224] and anhydrite $\left[\mathrm{CaSO}_{4} \mathrm{ICDD} 37-1496\right]$ appear in very scarce quantity. The presence of small quantities of gypsum could indicate its incorporation as an additive, with functions already highlighted in the literature (gypsum rends the lime mortar more white and increase the plasticity and the adherence of the mortar) [17]. Also this presence can indicate a certain degree of sulphatation of the carbonated material [18]. And, of course, it could be incorporated to the mortar through the aggregate that would have a certain amount of phases of gypsum in its composition.

However, the primary origin of the gypsum phases most probably should not be the limestone source of the binding material, because it could not have rehydrated to form $\mathrm{CaSO}_{4} \cdot 2 \mathrm{H}_{2} \mathrm{O}$ after have been heated till near $1000^{\circ} \mathrm{C}$ in the calcination of the limestone [17].

They are also observed by means of XRD clay minerals coming from some impurities, so much derived from the binder as from the aggregate. Their determination has been complicated because [19]:

i) The most intense diffraction peaks of most of these compounds appear within a narrow range, and generally the samples contain mixtures of these compounds in different proportions;

ii) The small quantity usually present means that either the diffraction peaks may not have stood out enough, or they may have been masked by the main components.

However, it can be seen very scarce quantity of muscovite $\left[\left(\mathrm{K}_{0.94} \mathrm{Al}_{1.96}\right)\right.$ $\left.\left(\mathrm{Al}_{0.95} \mathrm{Si}_{2.85} \mathrm{O}_{10}\right)\left((\mathrm{OH})_{1.744} \mathrm{~F}_{0.256}\right)\right]$, anorthite $\left[\mathrm{Ca}\left(\mathrm{Al}_{2} \mathrm{Si}_{2} \mathrm{O}_{8}\right)\right]$ and anorthoclase $\left[\left(\mathrm{Na}_{0.85} \mathrm{~K}_{0.15}\right)\right.$ $\left.\left(\mathrm{AlSi}_{3} \mathrm{O}_{8}\right)\right]$. Other clay minerals appear in a lower amount than the previously mentioned, as 
albite $\left[\mathrm{Na}\left(\mathrm{AlSi}_{3} \mathrm{O}_{8}\right)\right.$ ICDD 76-898], feldspar [( $\left.\mathrm{Na}_{0.5} \mathrm{~K}_{0.5}\right) \mathrm{AlSi}_{3} \mathrm{O}_{8}$ ICDD 84-710], kaolinite $\left[\mathrm{Al}_{2}\left(\mathrm{Si}_{2} \mathrm{O}_{5}\right)(\mathrm{OH})_{4}\right.$ ICDD 83-0971], and illite $\left[\mathrm{K}_{0.5}(\mathrm{Al}, \mathrm{Fe}, \mathrm{Mg})_{3}(\mathrm{Si}, \mathrm{Al})_{4} \mathrm{O}_{10}(\mathrm{OH})_{2}\right.$ ICDD 090343], in some samples.

The important heterogeneity of the studied samples, as can be seeing through the chemical analysis and the XRD, may be highlighted:

- $\quad$ There are samples with calcite and quartz as main components, but with significant presence of dolomite, that reveals the dolomitic origin of the raw limestones (samples Z1, Z2, Z6, Z7, Z9).

- $\quad$ In other samples, the dolomite appears as the main phase $(\mathrm{Z} 4, \mathrm{Z5}, \mathrm{Z8}, \mathrm{Z10})$, in fact with variable amounts of other important mineralogical phases.

- $\quad$ And even in the sample Z3 appears dolomite only in traces, being the hexagonal calcite the main mineralogical phase.

It can also be observed by means of XRD the presence of other magnesium carbonates different to dolomite, although in amount of traces. Usually nesquehonite $\left[\left(\mathrm{MgCO}_{3} \cdot 3 \mathrm{H}_{2} \mathrm{O}\right)\right.$ ICDD $20-$ 0669] appears but, in some cases could be hydromagnesite $\left[\left(\mathrm{Mg}_{5}\left(\mathrm{CO}_{3}\right)_{4}(\mathrm{OH})_{2} \cdot 4 \mathrm{H}_{2} \mathrm{O}\right)\right.$ ICDD $70-$ 1177] or, less probably, artinite $\left[\left(\mathrm{Mg}_{2} \mathrm{CO}_{3}(\mathrm{OH})_{2} \cdot 3 \mathrm{H}_{2} \mathrm{O}\right)\right.$ ICDD 06-0484].

In any event, none of these compounds are clearly appreciated by XRD. It could be made the hypothesis that they are not in a very crystalline state and/or they are present in a very scarce amount.

Contrary to what are pointed out in some works of the literature of dolomitic mortars [6-8], hydromagnesite do not appear clearly in the XRD study.

\subsubsection{Thermal studies}

Initial tests carried out with standards in several experimental conditions (type of crucible, atmosphere and heating rate), show the included conditions as the most appropriate for this type of materials (alumina crucible covered with a holed lid of alumina, heating rate $20^{\circ} \mathrm{C} \min ^{-1}$ in static air atmosphere). The use of an alumina holed lid on the crucible has shown great 
importance as can be seen later on. The summarised results of the thermal analysis are collected in Table 3.

Sample Z1 (Fig. 2) presents a DTA curve characterised by two important endothermic peaks, with associated weight losses at ca. $145^{\circ} \mathrm{C}$ and at ca. $850^{\circ} \mathrm{C}$. First of them appears as a doublet (clearly visible in the DTG curve) at $130^{\circ} \mathrm{C}$ and at $150^{\circ} \mathrm{C}$. This doublet could be associate, besides a possible loss of moisture, to the dehydration of the gypsum $\left(\mathrm{CaSO}_{4} \cdot 2 \mathrm{H}_{2} \mathrm{O}\right)$ that takes place in two stages Eqs.(1),(2) [20]:
$\mathrm{CaSO}_{4} \cdot 2 \mathrm{H}_{2} \mathrm{O} \rightarrow \mathrm{CaSO}_{4} \cdot 1 / 2 \mathrm{H}_{2} \mathrm{O}+3 / 2 \mathrm{H}_{2} \mathrm{O}$
$\mathrm{T} \approx 162^{\circ} \mathrm{C}$
(Eq. 1)
$\mathrm{CaSO}_{4} \cdot 1 / 2 \mathrm{H}_{2} \mathrm{O} \rightarrow \mathrm{CaSO}_{4}+1 / 2 \mathrm{H}_{2} \mathrm{O}$
$\mathrm{T}^{\mathrm{a}} \approx 174^{\circ} \mathrm{C}$

The second one would be associate to the decarbonation of the calcite and the weight loss has been related to the $\mathrm{CO}_{2}$ evolution from the structure (Eq. 3) [21]:

$\mathrm{CaCO}_{3} \rightarrow \mathrm{CaO}+\mathrm{CO}_{2} \quad \mathrm{~T}^{\mathrm{a}} \approx 860^{\circ} \mathrm{C}$

Besides these two important endothermic peaks, other peak at ca. $700^{\circ} \mathrm{C}$ can be observed. This peak could correspond to the thermal decomposition of the dolomite, $\mathrm{CaMg}\left(\mathrm{CO}_{3}\right)_{2}$ [22,23] determined by means of XRD, although in small amount. The peak could correspond to decomposition of the $\mathrm{MgCO}_{3}$ from the dolomite, the weight loss being due to the $\mathrm{CO}_{2}$ evolution. At the same temperature $\left(850^{\circ} \mathrm{C}\right)$ that the $\mathrm{CaCO}_{3}$ from the calcite, the remaining calcium carbonate from the dolomite lattice could loss the $\mathrm{CO}_{2}$; so the peaks appear overlapped $[21]$.

In the DTA curve, an endothermic peak without associated weight loss has been observed at $573^{\circ} \mathrm{C}$. This peak could be related with the transformation (Eq. 4):

$\alpha$-quartz $\rightarrow$-quartz $\quad \mathrm{T}^{\mathrm{a}} \approx 573^{\circ} \mathrm{C}$

The energy involved in this polymorphous inversion is small; obviously the corresponding endothermic peak is also very small [24].

The weight loss associated with the endothermic peak at approx. $145^{\circ} \mathrm{C}$ is, nevertheless, too important for the amount of gypsum determined in the sample (by XRD and by the chemical 
analysis - percentage of $\mathrm{SO}_{3}$ ). Therefore, in this same range of temperatures, it could have other weight losses corresponding to other compounds. For example $\mathrm{Mg}\left(\mathrm{HCO}_{3}\right)(\mathrm{OH}) 2 \mathrm{H}_{2} \mathrm{O}$ (nesquehonite, $\mathrm{MgCO}_{3} 3 \mathrm{H}_{2} \mathrm{O}$ ), that appears in the X-ray diffraction pattern in scarce amounts $(<5 \%)$. This substance loses two molecules of water around $200^{\circ} \mathrm{C}$, and it could be the cause of the increase of weight loss. This compound has been pointed out as one of the possible resultants of the $\mathrm{Mg}(\mathrm{OH})_{2}$ carbonation [21].

Either the endothermic effects at $440^{\circ} \mathrm{C}$ and $530^{\circ} \mathrm{C}$ for hydromagnesite or the exothermic peak with weight loss associated at $510^{\circ} \mathrm{C}$ have not been observed [21]. The presence of $\mathrm{HY}$ in this mortar has not been determined by means of thermal analysis. This result shows an agreement with XRD determination.

In the thermal studies of the sample Z2 similar results were obtained (Table 3). Gypsum, quartz and calcite clearly show their thermal effects. Dolomite is present in small amount and apparently not very crystalline, as the irregularity of the curve shows, but the endothermic peak in DTA curve can be determined.

A last endothermic peak between $900^{\circ}$ and $1000^{\circ} \mathrm{C}$, with associated weight loss, has been observed in the study. There are two possible explanations for this endothermic effect:

i) The muscovite $\left(\mathrm{K}_{0.94} \mathrm{Al}_{1.96}\right)\left(\mathrm{Al}_{0.95} \mathrm{Si}_{2.85} \mathrm{O}_{10}\right)\left((\mathrm{OH})_{1.744} \mathrm{~F}_{0.256}\right)$ detected by XRD releases structural water at $900^{\circ} \mathrm{C}$, breaking the crystal lattice [20].

ii) After melting, $\mathrm{NaCl}$ and $\mathrm{KCl}$ evaporate at these temperatures, what would justify the weight loss and the high contents of $\mathrm{Na}$ and $\mathrm{K}$ determined by the chemical analysis $[8,20]$.

Although the first hypothesis is qualitatively sound with the XRD results, quantitatively it seems an excessive weight loss for the detected muscovite by XRD. So, perhaps, the effect can be due to the combination of the two hypothesis.

In the study of Z3 sample, gypsum in small amount, quartz and calcite have been also showed their endothermic effects. In the study by XRD, dolomite appears in amount of traces. The 
weight loss observed at ca. $700^{\circ} \mathrm{C}$ could be due, as in the previous sample, to the $\mathrm{MgCO}_{3}$. $\mathrm{The}$ remaining $\mathrm{CaCO}_{3}$ should have foreseeably overlap with the peak of calcite decomposition.

In connection with the samples Z4 and Z5 (Table 3), traces of gypsum could be present. The weight loss around $320^{\circ} \mathrm{C}$ (sample Z5, Fig. 3) could be attributed to the dehydration of some magnesium carbonate that could have been formed, as for example the nesquehonite, $\mathrm{MgCO}_{3} \cdot 3 \mathrm{H}_{2} \mathrm{O}$, (determined in traces by XRD). The endothermic peak in DTA curve is not well defined, hence the material could have a poor crystallinity.

The three endothermic peaks at ca. $690^{\circ}$, ca. $730^{\circ}$ and ca. $900^{\circ} \mathrm{C}$ (Fig. 3) could be justified for a dolomite with a poor crystallinity, like a dolomitized magnesite or a mixture of magnesium and calcium carbonates, due to the decrease of the characteristic initial temperature of the first peak of dolomite and to the appearance of a relatively erratic weight loss. The absence of magnesite phases (Table 2, results of XRD), the typical presence of dolomite in magnesium limestones (and not of magnesite), and the consideration of the poor crystallinity of the material, take better to think therefore on a poor crystallinity dolomite [21].

Thermal studies of the samples Z6, Z7 and Z9, with calcite and quartz as main phases, and a little amount of dolomite, show an agreement with the studies by XRD and by the chemical analysis. The presence of small amounts of clay minerals as muscovite, illite and kaolinite, determined by XRD, could justify the high contents of $\mathrm{R}_{2} \mathrm{O}_{3}\left(\mathrm{Al}_{2} \mathrm{O}_{3}, \mathrm{Fe}_{2} \mathrm{O}_{3}\right.$ and $\left.\mathrm{TiO}_{2}\right)$ in these samples in the chemical analysis results, and the partial loss of the water of these compounds around $300^{\circ} \mathrm{C}$.

In the study of the samples Z8 and Z10, two endothermic peaks, with associated weight losses, have been determined. The peaks could correspond to the decomposition of $\mathrm{MgCO}_{3}$ of the dolomite, very abundant in the sample, around $800^{\circ} \mathrm{C}$, and to the decomposition of the $\mathrm{CaCO}_{3}$ coming from the calcite and the dolomite, which decompose at the same temperature and justify the absence of a point of inflection, around $900^{\circ} \mathrm{C}$. 


\subsection{Preparation and study of simulated standards}

As it has already been pointed out, contrary to what it is noticed in several works of specialised literature $[6-8,13,25]$, that it has not been able to determine the presence of hydromagnesite (HY) in mortars of dolomitic origin of Santa María de Zamarce. It has motivated the preparation of samples with different mixtures of typically present compounds in limestone or dolomitic mortars. The aim of the preparation of these mixtures was to clarify the sensitivity and specificity of the analytical techniques used in the study for the determination of HY (XRD and TGA-DTA, mainly). According to the results, the preliminary conclusion of the absence of HY in mortars of Santa María de Zamarce could be considered or not as definitive. The prepared mixtures and their proportion (weight/weight) are presented in Table 4, together the semiquantitative results of XRD.

\subsection{1. $\underline{X R D \text { studies }}$}

The obtained results show that it is really possible to determine HY by means of XRD (70-1177 ICDD standard, pure HY). Nevertheless when HY is mixed with other compounds, the intensity of its peaks of diffraction is very weak, being undetectable in some cases $[\mathrm{HY}+\mathrm{C}$ (1:5), HY + C + Q (1:6:12), HY + P + Q (1:6:12)] (as example, Fig. 4 shows XRD patterns of the mixtures of $\mathrm{HY}+\mathrm{C}$, with the gradual decrease of the intensity of the HY diffraction). This event had been already indicated in a previous work [13]. In this paper, Bruni et al. explain that, in comparison with the calcite specially, the poor crystallinity of the HY is the cause of the weak intensity of the peaks, emphasizing that the HY peaks could not be detected in small amounts. Actually, in the present work, when calcite is present, the attenuation of the HY peaks is so high that the peaks are undetectable or almost undetectable for amounts in weight between $20 \%$ and $16 \%[(\mathrm{HY}+\mathrm{C}(1: 4)$ and $(1: 5)]$. This fact could be justified by the poor crystallinity of the hydroxisal and the large presence of hydrogen atoms by weight formula.

So, the results of XRD of the samples of Santa María de Zamarce can not be considered definitive to verify the absence of HY in these mortars, because relatively large amounts could 
escape to the detection by $\mathrm{XRD}$, especially considering that calcite is present in all those mortars. Surprisingly, the previously cited works $[7,8]$ have not shown problems in the determination of HY by XRD in samples with important contents of calcite.

\subsubsection{Thermal studies}

In connection with thermal analysis, Dheilly et al. [7] have not used it in their work. A different thermal behaviour between the pure HY and the samples of ancient mortars studied has been observed by Vecchio et al. [8]. The authors have determined a sharp exothermic peak at $500^{\circ} \mathrm{C}$ in pure HY. The authors have been related it to the crystallization of a mixed oxocarbonate phase $\left(\mathrm{xMgCO}_{3} \mathrm{yMgO}\right)$. Thermal analysis of pure $\mathrm{HY}$ (Fig. 5) is similar to the obtained by these authors and other bibliographical references [14,21]. It can be observed the exothermic peak at ca. $500^{\circ} \mathrm{C}$.

DTA curves of samples from ancient mortars studied by Vecchio et al. [8] have not presented the exothermic peak of $\mathrm{HY}$ at $500^{\circ} \mathrm{C}$. The behaviour of mixtures of $\mathrm{HY}$ and calcite in different proportions has been used by the authors in order to explain the absence of this sharp exothermic peak. They have indicated that the presence of impurities (chlorides or calcium compounds) hinders the crystallization of the oxocarbonate phase $\left(\mathrm{xMgCO}_{3} \mathrm{yMgO}\right)$, during the HY thermal decomposition. In the referred study, samples with molar relations $\mathrm{Ca} / \mathrm{Mg}$ greater than 2 have been shown.

In this regard it is possible to make the following considerations:

i) One of the references of the work by Vecchio et al. [8] is a study about the thermal decomposition of HY made by Sawada et al. [14]. The work by Sawada et al. has not related the crystallization of a magnesium oxocarbonate phase as responsible of the exothermic peak at $500^{\circ} \mathrm{C}$. In accordance with Sawada et al., the exothermic peak must be consequence of the crystallization of an amorphous phase of $\mathrm{MgCO}_{3}$. No the crystallization of $\mathrm{MgO}$ is responsible for the exothermic phenomenon. 
ii) The effect of calcium impurities, calcite for example, on the occurrence of the exothermic peak at least is debatable. Some mixtures prepared in the work by Vecchio et al. (HY $+\mathrm{C}(1: 1)$ and $(1: 2))[8]$ have shown the exothermic peak clearly. The samples studied in the present work allow to observe the exothermic peak at $500^{\circ} \mathrm{C}$ in all cases (Table 5). Even being mixtures with low weight percentage of HY with respect to calcite (molar relationships $\mathrm{Mg}: \mathrm{Ca}(1: 4)$ or less), and also with regard to other present phases. In all cases, the exothermic peak at $500^{\circ} \mathrm{C}$ is observed. As example, the mixture $\mathrm{HY}+\mathrm{C}(1: 5)$ is showed: it can be seen the thermal phenomena corresponding to the HY (endothermic at $320^{\circ} \mathrm{C}, 440^{\circ} \mathrm{C}$ and $550^{\circ} \mathrm{C}$, and exothermic at $510^{\circ} \mathrm{C}$ ) and to the calcite (decomposition at $800-900^{\circ} \mathrm{C}$ ) (Fig. 6).

iii) This exothermic crystallization of $\mathrm{MgCO}_{3}$ usually is accompanied of a rapid evolution of carbon dioxide by decomposition of the $\mathrm{MgCO}_{3}$ formed. This decomposition is strongly dependent of the temperature: a slight increase of the sample temperature leads to a drastic increase in the decomposition rate [14].

A weight loss due to the aforementioned fact, immediately after the exothermic phenomenon, has been observed in the samples analysed in the present work.

Bruni et al. [6] have also used the thermal analysis as method of identification of phases, specifically HY, on five samples of different centuries taken in different restoration works. In this work, four endothermic peaks at $250^{\circ}, 350^{\circ}, 410^{\circ}$ and $480^{\circ} \mathrm{C}$ have been mentioned. The authors have ascribed these peaks to the dehydration of the HY, to the loss of hydroxyl water in the HY, to the decomposition of carbonate of HY, and to the decomposition of the magnesite, respectively. These attributions of the endothermic peaks are, partly, similar to the observed ones by Webb and Krüger [21] who take into account as well a work of Beck [26] also cited by the authors. 
Avoiding the differences in the temperatures of decomposition, which depend of some factors as the degree of crystallinity and the grain size of the sample, it can indicate that the work of Bruni et al. [6] says nothing about the absence of the exothermic peak at ca. $500^{\circ} \mathrm{C}$.

The attribution of loss of hydroxil water at ca. $350^{\circ} \mathrm{C}$, after occurring the dehydration at ca. $250^{\circ} \mathrm{C}$, is also questionable. Sawada et al. [14], by means of differential thermal gas analysis (DTGA) and DTA have determined in HY a dehydration at $100-300^{\circ} \mathrm{C}$, and three decarbonation stages at high $\mathrm{CO}_{2}$ pressure $\left(\mathrm{P}_{\mathrm{CO} 2}\right)$, at ca. $350-510^{\circ} \mathrm{C}$, ca. $520^{\circ} \mathrm{C}$ and ca. $530-$ $650^{\circ} \mathrm{C}$. At low $\mathrm{P}_{\mathrm{CO} 2}$, only one decarbonation peak in DTGA has been observed. Moreover, the authors have indicated a change of the HY structure after the complete dehydration, with the appearance of an amorphous diffraction pattern. At approx. $500^{\circ} \mathrm{C}$ the specimen was formed by crystalline $\mathrm{MgO}$ (crystallite size ca. $50 \AA$ ) and an amorphous phase including magnesium carbonate. The composition was approximately $2,6 \mathrm{MgCO}_{3} \cdot 3,2 \mathrm{MgO}$. As it has been pointed out, the transformation of $\mathrm{MgCO}_{3}$ from the amorphous phase to the crystalline phase could be the responsible for the sharp exothermic peak.

The results of Beck [26] had already been questioned by Sawada et al. [14]. The attributions of endothermic peaks made by Fiori and Macchiarola [25] are equally debatable.

After these considerations it arises the question that if the thermal studies are useful to verify the presence of HY in ancient binding materials. The experimental conditions seem to be very important. On this matter it can be indicated:

i) Sawada et al. [14] have studied the thermal HY decomposition in two experimental conditions: one with low $\mathrm{CO}_{2}$ pressure $\left(\mathrm{P}_{\mathrm{CO} 2}=0.00\right.$ bar $)$, and another one with high $\mathrm{CO}_{2}$ pressure $\left(\mathrm{P}_{\mathrm{CO} 2}=0.50\right.$ bar $)$. For the occurrence of the exothermic phenomenon at ca. $500^{\circ} \mathrm{C}$ a high $\mathrm{P}_{\mathrm{CO} 2}$ was required, as well as for the occurrence of the three stages of HY decarbonation.

ii) In the simplest case, this high $\mathrm{P}_{\mathrm{CO} 2}$ can be applied externally. But, in addition to this, the authors set out the establishment of this high $\mathrm{P}_{\mathrm{CO} 2}$ around the sample (self-generated 
atmosphere), when the sample powder was densely packed or the heating rate exceeded the rate of ventilation.

iii) In the present work, these experimental conditions have been guaranteed with a static air atmosphere, the packed sample and a high heating rate $\left(20^{\circ} \mathrm{C} \min ^{-1}\right)$. Furthermore alumina crucibles have been used with holed lids. The obtained results in the studied samples have been satisfactory.

iv) The identification of the set of phenomena of thermal HY decomposition (including the exothermic phenomenon) and of other present phases, has been possible in all the studied simulated standards. Practically significant displacements in the temperatures of the different thermal phenomena have not taken place, in accordance with literature data $[14,21]$.

\subsection{Discussion}

Regarding the obtained results, the determination of HY in prepared specimens has been possible even in samples with small percentage of HY (Fig. 6 shows the set of phenomena of thermal decomposition of HY in the DTA curve of $\mathrm{HY}+\mathrm{C}(1: 5)$, with scarce amount of $\mathrm{HY})$. In the experimental conditions considered in this work, the ability of the thermal studies, in order to identify the different present phases in a dolomitic binding material, has been checked. It can be confirmed the absence of HY, at least in significant amounts, in the analysed ancient mortars of Santa María de Zamarce, since the thermal characteristic phenomena of HY have not been observed.

The variability in the showed results in previous works of other authors could be due to the different experimental conditions, especially the heating rate and the experimental atmosphere $[15]$.

On the other hand, the absence of HY in ancient dolomitic binding materials of Santa María de Zamarce it is surprising. HY has been referred in dolomitic mortars by several authors [6$8,13,25]$. Some hypothesis can be considered: 
i) In some cases found in the bibliography, it could be nesquehonite $\left(\mathrm{MgCO}_{3} \cdot 3 \mathrm{H}_{2} \mathrm{O}\right)$, with similar losses in those ranks of temperatures, the referred phase instead of HY. Nevertheless, the small amount present in the studied mortars as well as some contradictory results of the literature have complicated this discussion.

ii) The absence of HY in these materials could be justified if it considers the addition of dolomite as aggregate. On this supposition, dolomite would has not undergone previous burnt, therefore during the setting HY would has not been formed.

This hypothesis contrasts with: a) the occurrence of one silica aggregate in the samples; b) the occurrence of samples which dolomite is the main present phase; c) the difficulty to have a pure lime in order to be used as binder, and a dolomitic lime in order to be used as aggregate, because usually raw materials available "in situ" were used. Regarding this matter, this hypothesis is very unlikely [10].

iii) It could be put forward the occurrence of dolomite phases as a result of a poor burning process of dolomitic limestone, but it could not justify either the behaviour of the burned fraction or some of the aforementioned problems [10].

Finally, without put into question the occurrence of HY in dolomitic mortars, its presence in the samples of Santa María de Zamarce studied in this work has not been established, at least in significant amounts. Perhaps the required conditions of preparation of these ancient binding materials were specific, or the raw material was different. On this matter, in the work by Dheilly et al. [7] HY has been obtained after curing in excess of $\mathrm{CO}_{2}$. The conclusions of the work by Bruni et al. [6] about the carbonation of lime with $\operatorname{Mg}(\mathrm{OH})_{2}$ and of the work by Vecchio et al. [8] about the determination of phases are partly questionable. Therefore, there will be necessary further studies with the aim of clarify the reasons and the conditions of occurrence of HY in mortars of dolomitic origin. 


\section{Conclusions}

All then analysed ancient mortars of the church of Santa María de Zamarce are of dolomitic origin, being dolomite, calcite and quartz the main mineralogical phases. It has not been possible determine by XRD or TGA-DTA the occurrence of hydromagnesite (hydrated magnesium carbonate hydroxide, HY) in any of the studied mortars, either in its individual study or by comparison with standard mixtures.

On the contrary, the exothermic peak at ca. $500^{\circ} \mathrm{C}$ which was observed in the HY thermal decomposition, due to the crystallization of $\mathrm{MgCO}_{3}$ from the amorphous phase, has been observed in the 16 standard samples, in the aforementioned experimental conditions. Even the samples with small weight percentage of HY have clearly shown the set of phenomena of HY thermal decomposition (including the exothermic peak at $510^{\circ} \mathrm{C}$ ).

By XRD, an important toning down of the intensity of the HY diffraction peaks has been observed when HY is mixed with calcium compounds (calcite and portlandite). Occasionally, with HY in relatively small amounts (even around $25 \%$ in weight/weight), its diffraction peaks could be masked. In this situation, the use of XRD in conjunction with TGA-DTA is very suitable.

The analysis of these standard samples has revealed as very adequate for the study of dolomitic binding materials the experimental conditions in TGA-DTA with a high $\mathrm{P}_{\mathrm{CO} 2}$ around the sample (static air atmosphere, packed sample, high heating rate $\left(20^{\circ} \mathrm{C} \min ^{-1}\right)$ and alumina crucibles with holed lids).

\section{Acknowledgements}

The present study was supported by the spanish Ministerio de Ciencia Tecnología, Plan Nacional de Investigación, Desarrollo e Innovación Tecnológica ( + +D+I) programme, Project MAT2000-1347. 


\section{References}

[1] C. Rodríguez-Navarro, E. Hansen, W. S. Ginell, J. Am. Ceram. Soc., 81 (11) (1998), 30323034.

[2] Conclusions of the Symposium "Mortars, cements and grouts used in the conservation of historic buildings”, Rome, Mater. Struct., 23 (1990) p.235.

[3] M. Franzini, L. Leoni, M. Lezzerini, Journal of Cultural Heritage 1 (2000) 365-373.

[4] M. Frizot, in Université de Dijon (Ed.), Centre de Recherches sur les techniques gréco-romains, 1975, pp. 57-137.

[5] F. Gutiérrez-Solana, M. Jauregui, R. Bohigas, P. Sarabia, Mater. Construcc. 39 (213) (1989) 37-45.

[6] S. Bruni, F. Cariati, P. Fermo, A. Pozzi, L Toniolo, Thermochim. Acta 321 (1998) 161-165.

[7] R.M. Dheilly, A. Bouguerra, B. Beaudoin, J. Tudo, M. Queneudec, Mat. Sci. Eng. A - Struct. 268 (1999) $127-131$.

[8] S. Vecchio, A. Laginestra, A. Frezza, C. Ferragina, Thermochim. Acta 227 (1993) 215-223.

[9] R.G. Newton, J.H. Sharp, Stud. Conserv. 32 (1987) 163-175.

[10] G. Alessandrini, R. Bugini, R. Negrotti, L. Toniolo, Eur. J. Mineral. 3 (1991) 619-627.

[11] A. Botha, C.A. Strydom, Hydrometallurgy 62 (2001) 175-183.

[12] P.G. Caceres, E.K. Attiogbe, Minerals Engineering 10 (10) (1997) 1165-1176.

[13] S. Bruni, F. Cariati, P. Fermo, P. Cairati, G. Alessandrini, L. Toniolo, Archaeometry 39 (1) (1997) 1-7.

[14] Y. Sawada, K. Uematsu, N. Mizutani, M. Kato, Thermochim. Acta 27 (1978) 45-49.

[15] N. Khan, D. Dollimore, K. Alexander, F.W. Wilburn, Thermochim. Acta 367-368 (2001) 321333.

[16] J.I. Alvarez, I. Navarro, P.J. García Casado, Termochim. Acta 365 (2000) 177-187.

[17] G. Martinet, F. Deloye, J.C. Golvin, Bull. liaison Labo. P. et Ch. 181 (1992) 39-45. 
[18] C. Sabbioni, G. Zappia, C. Riontino, M.T. Blanco-Varela, J. Aguilera, F. Puertas, K. Van Balen, E.E. Toumbakari, Atmos. Environ. 35 (2001) 539-548.

[19] J.I. Alvarez, I. Navarro, A. Martín, P.J. García Casado, Cem. Concr. Res. 30 (2000) 14131419.

[20] T. Hatakeyama, Z. Liu, Handbook of Thermal Analysis, John Wiley \& Sons Ltd (Eds.), England, 1998.

[21] T.L. Webb, J.E. Krüger, in R.C. Mackenzie (Ed.) Differential Thermal Analysis, Academic Press Inc. (London), 1970, pp. 303-341.

[22] M. Samtani, D. Dollimore, F.W. Wilburn, K. Alexander, Thermochim. Acta 367-368 (2001) 285-295.

[23] M. Samtani, D. Dollimore, K. Alexander, Thermochim. Acta 6983 (2002) 1-11. Article in press.

[24] R.G. Newton, J.H. Sharp, Cem. Concr. Res. 17 (1987) 77-80.

[25] C. Fiori, M. Macchiarola, in E.M. Sebastián Pardo, I. Valverde Espinosa, U. Zezza (Eds.), III Congreso Internacional de Rehabilitación del Patrimonio Arquitectónico y Edificación, Granada (España), 1996, pp. 223-237.

[26] C. W. Beck, Am. Miner. 35 (1950) 985-1013. 
Table 1. Chemical analysis of the main components of the mortars of Santa María de Zamarce

\begin{tabular}{ccccccccc}
\hline Sample & $\mathbf{L o s s}^{\mathbf{a}}$ & $\begin{array}{c}\mathbf{S i O}_{\mathbf{2}}^{\mathbf{b}} \\
\mathbf{( \% )}\end{array}$ & $\begin{array}{c}\mathbf{C a O} \\
\mathbf{( \% )}\end{array}$ & $\begin{array}{c}\mathbf{M g O} \\
\mathbf{( \% )}\end{array}$ & $\begin{array}{c}\mathbf{R}_{\mathbf{2}} \mathbf{O}_{\mathbf{3}}{ }^{\mathbf{c}} \\
\mathbf{( \% )}\end{array}$ & $\begin{array}{c}\mathbf{S O}_{3} \\
\mathbf{( \% )}\end{array}$ & $\begin{array}{c}\mathbf{N a}_{\mathbf{2}} \mathbf{O} \\
(\mathbf{\%})\end{array}$ & $\begin{array}{c}\mathbf{K}_{\mathbf{2}} \mathbf{O} \\
\mathbf{( \% )}\end{array}$ \\
\hline $\mathbf{Z 1}$ & 23.97 & 35.27 & 16.38 & 10.18 & 10.00 & 1.44 & 0.60 & 1.26 \\
$\mathbf{Z 2}$ & 13.88 & 51.33 & 14.08 & 3.52 & 8.18 & 6.52 & 0.77 & 1.33 \\
$\mathbf{Z 3}$ & 30.45 & 23.11 & 30.56 & 4.82 & 9.15 & 0.92 & 0.50 & 0.90 \\
$\mathbf{Z 4}$ & 30.50 & 31.79 & 22.48 & 9.35 & 4.06 & 0.41 & 0.11 & 0.21 \\
$\mathbf{Z 5}$ & 45.56 & 3.08 & 34.39 & 14.32 & 1.53 & 0.61 & 0.24 & 0.31 \\
$\mathbf{Z 6}$ & 26.32 & 34.93 & 26.84 & 3.53 & 7.66 & 0.10 & 0.07 & 0.18 \\
$\mathbf{Z 7}$ & 24.67 & 38.03 & 26.88 & 2.53 & 7.56 & 0.37 & 0.22 & 0.67 \\
$\mathbf{Z 8}$ & 42.97 & 3.46 & 36.35 & 15.63 & 0.64 & 0.33 & 0.24 & 0.10 \\
$\mathbf{Z 9}$ & 35.10 & 18.04 & 34.83 & 5.33 & 5.57 & 0.58 & 0.24 & 0.41 \\
$\mathbf{Z 1 0}$ & 43.33 & 2.07 & 36.57 & 13.57 & 3.44 & 0.24 & 0.04 & 0.04 \\
\hline
\end{tabular}

Sodium carbonate-borax alkaline flux.

Percentages related to original dry mortar.

${ }^{a}$ Loss indicates the loss due to calcination at $975-1000^{\circ} \mathrm{C}$.

${ }^{\mathrm{b}}$ The percentages of $\mathrm{SiO}_{2}$ refers to the total silica in the sample.

${ }^{c} \mathrm{R}_{2} \mathrm{O}_{3}$ expresses the percentage of $\mathrm{Fe}, \mathrm{Al}$ and $\mathrm{Ti}$ as oxides.

Table 2. Results of X-ray diffraction in mortars of Santa María de Zamarce

\begin{tabular}{|c|c|c|c|c|c|c|c|}
\hline Sample & $\begin{array}{c}\alpha \text {-quartz } \\
\left(\mathrm{SiO}_{2}\right)\end{array}$ & $\begin{array}{c}\text { calcite } \\
\left(\mathrm{CaCO}_{3}\right)\end{array}$ & $\begin{array}{c}\text { dolomite } \\
\left(\mathrm{CaMg}\left(\mathrm{CO}_{3}\right)_{2}\right)\end{array}$ & $\begin{array}{c}\text { gypsum } \\
\left(\mathrm{CaSO}_{4} \cdot 2 \mathrm{H}_{2} \mathrm{O}\right)\end{array}$ & $\begin{array}{c}\text { muscovite } \\
\left(\mathrm{K}_{0,94} \mathrm{Al}_{1,96}\right) \\
\left(\mathrm{Al}_{0.95} \mathrm{Si}_{2,85} \mathrm{O}_{10}\right) \\
\left((\mathrm{OH})_{1.744} \mathrm{~F}_{0,256}\right)\end{array}$ & $\begin{array}{c}\text { anorthite } \\
\mathrm{Ca}\left(\mathrm{Al}_{2} \mathrm{Si}_{2} \mathrm{O}_{8}\right)\end{array}$ & $\begin{array}{l}\text { anorthoclase } \\
\qquad\left(\mathrm{Na}_{0.85} \mathrm{~K}_{0.15}\right) \\
\left(\mathrm{AlSi}_{3} \mathrm{O}_{8}\right)\end{array}$ \\
\hline & ICDD 85-798 & ICDD 05-0586 & ICDD 36-0426 & ICDD 21-0816 & ICDD 86-1386 & ICDD 76-948 & ICDD 75-1635 \\
\hline Z1 & $*$ & $*$ & S & $\mathrm{T}$ & - & $\mathrm{T}$ & - \\
\hline $\mathrm{Z2}$ & $* *$ & $*$ & $\mathrm{~S}$ & $\mathrm{~S}$ & $\mathrm{~T}$ & $\mathrm{~T}$ & $\mathrm{~S}$ \\
\hline Z3 & $*$ & $* *$ & $\mathrm{~T}$ & - & - & $\mathrm{T}$ & $\mathrm{S}$ \\
\hline Z4 & $*$ & $\mathrm{~S}$ & $*$ & - & - & $\mathrm{T}$ & $\mathrm{T}$ \\
\hline Z5 & $\mathrm{T}$ & S & $* *$ & - & - & - & - \\
\hline Z6 & $*$ & $*$ & $\mathrm{~S}$ & - & $\mathrm{T}$ & $\mathrm{T}$ & - \\
\hline Z7 & $*$ & $*$ & $\mathrm{~S}$ & - & $\mathrm{T}$ & $\mathrm{T}$ & $\mathrm{T}$ \\
\hline Z8 & $\mathrm{T}$ & $*$ & $* *$ & - & - & - & - \\
\hline Z9 & $*$ & $* *$ & $\mathrm{~S}$ & - & - & $\mathrm{T}$ & - \\
\hline Z10 & $\mathrm{T}$ & $*$ & $* *$ & - & - & - & - \\
\hline
\end{tabular}

S : small amount (5-20\%)

$\mathrm{T}:$ traces $(<5 \%)$

*: $\quad 20-50 \%$

- : undetectable

$* *: \quad 50-75 \%$

$* * *: \quad>75 \%$ 
Table 3. Summary of the results of the thermal analysis (DTA, TG and DTG curves). Associate compounds to the thermal events.

\begin{tabular}{|c|c|c|c|c|c|c|c|c|}
\hline \multirow[b]{2}{*}{ Samples } & \multirow[b]{2}{*}{ Curve } & \multicolumn{2}{|r|}{ Approximate } & \multicolumn{2}{|l|}{ temperatures $\left({ }^{\circ} \mathrm{C}\right)$} & \multirow[b]{2}{*}{$700^{\circ}$} & \multirow[b]{2}{*}{$900^{\circ}$} & \multirow[b]{2}{*}{ Other effects } \\
\hline & & $145^{\circ}$ & $320^{\circ}$ & $440^{\circ}, 510^{\circ}$ and $530^{\circ}$ & $573^{\circ}$ & & & \\
\hline \multirow{4}{*}{$\mathbf{Z 1}$} & DTA & $\downarrow$ & vs $\downarrow$ & - & vs $\downarrow$ & $\mathrm{s} \downarrow$ & $\downarrow$ & - \\
\hline & TG & $\downarrow$ & vs $\downarrow$ & - & - & $\mathrm{s} \downarrow$ & $\downarrow$ & - \\
\hline & DTG & Doublet $\left(130^{\circ}, 150^{\circ}\right)$ & - & - & - & Peak & Peak & - \\
\hline & Compounds & G & $\mathrm{N} ?$ & - & Q & $\mathrm{D}$ & $\mathrm{C}$ & - \\
\hline \multirow{4}{*}{$\mathbf{Z 2}$} & DTA & $\downarrow$ & - & - & $\mathrm{s} \downarrow$ & $\mathrm{vs} \downarrow$ & $\downarrow$ & $*$ \\
\hline & TG & $\downarrow$ & - & - & - & vs $\downarrow$ & $\downarrow$ & $*$ \\
\hline & DTG & Doublet $\left(162^{\circ}, 176^{\circ}\right)$ & - & - & - & Peak & Peak & $*$ \\
\hline & Compounds & $\mathrm{G}$ & - & - & Q & $\mathrm{D}$ & $\mathrm{C}$ & ${ }^{*}$ See text \\
\hline \multirow{4}{*}{ Z3 } & DTA & $\downarrow$ & - & - & $\mathrm{vs} \downarrow$ & vs $\downarrow$ & $\downarrow$ & - \\
\hline & TG & $\mathrm{s} \downarrow$ & - & - & - & vs $\downarrow$ & $\downarrow$ & - \\
\hline & DTG & Peak & - & - & - & Peak & Peak & - \\
\hline & Compounds & G & - & - & Q & $\mathrm{D}$ & $\mathrm{C}$ & - \\
\hline \multirow{4}{*}{$\mathrm{Z4}, \mathrm{Z5}$} & DTA & $\mathrm{vs} \downarrow$ & $\mathrm{vs} \downarrow$ & - & - & $\downarrow$ & $\downarrow$ & - \\
\hline & TG & $\mathrm{vs} \downarrow$ & $\mathrm{vs} \downarrow$ & - & - & $\downarrow$ & $\downarrow$ & - \\
\hline & DTG & Peak & - & - & - & $*$ Doublet $\left(690^{\circ}, 730^{\circ}\right)$ & Peak & - \\
\hline & Compounds & Traces of G & $\mathrm{N} ?$ & - & - & $*$ See text & $\mathrm{C}$ & - \\
\hline \multirow{4}{*}{ Z6, Z7, Z9 } & DTA & - & vs $\downarrow$ & - & vs $\downarrow$ & vs $\downarrow$ & $\downarrow$ & - \\
\hline & TG & - & $\mathrm{Vs} \downarrow$ & - & - & vs $\downarrow$ & $\downarrow$ & - \\
\hline & DTG & - & Peak & - & - & - & Peak & - \\
\hline & Compounds & - & Clay minerals & - & Q & Traces of D & $\mathrm{C}$ & - \\
\hline \multirow{4}{*}{ Z8, Z10 } & DTA & vs $\downarrow$ & - & - & - & $\downarrow$ & $\downarrow$ & - \\
\hline & TG & - & - & - & - & $\downarrow$ & $\downarrow$ & - \\
\hline & DTG & - & - & - & - & Peak & Peak & - \\
\hline & Compounds & Traces of G? & - & - & - & $\mathrm{D}$ & C & - \\
\hline
\end{tabular}

DTA curves: $\downarrow$ : endothermic peak; $\mathrm{s} \downarrow$ : slight endothermic peak; vs $\downarrow$ : very slight endothermic peak; -: no phenomenon observed

TG curves: $\downarrow$ : weight loss; $s \downarrow$ : slight weight loss; vs $\downarrow$ : very slight weight loss; -: no weight loss observed

Compounds: G: gypsum; N: nesquehonite; Q: quartz; D: dolomite; C: calcite. 
Table 4. Simulated standards (weight ratios) and X-ray diffraction results.

\begin{tabular}{|c|c|c|c|c|c|}
\hline \multirow[t]{2}{*}{$\begin{array}{l}\text { SIMULATED } \\
\text { STANDARDS }\end{array}$} & $\begin{array}{c}\text { hydromagnesite } \\
\text { (HY) } \\
\mathrm{Mg}_{5}\left(\mathrm{CO}_{3}\right)_{4} \\
(\mathrm{OH})_{2} \cdot 4 \mathrm{H}_{2} \mathrm{O}\end{array}$ & $\begin{array}{c}\text { calcite } \\
(\mathbf{C}) \\
\left(\mathrm{CaCO}_{3}\right)\end{array}$ & $\begin{array}{c}\alpha \text {-quartz } \\
\text { (Q) } \\
\left(\mathrm{SiO}_{2}\right)\end{array}$ & $\begin{array}{l}\text { portlandite } \\
\quad \text { (P) } \\
\left(\mathrm{Ca}(\mathrm{OH})_{2}\right)\end{array}$ & $\begin{array}{c}\text { periclase } \\
\text { (MgO) } \\
(\mathrm{MgO})\end{array}$ \\
\hline & ICDD 70-1177 & ICDD 05-0586 & ICDD 85-798 & ICDD 44-1481 & ICDD 45-0946 \\
\hline pure HY & $* * *$ & - & - & - & - \\
\hline HY + C (1:1) & $*$ & $* *$ & - & - & - \\
\hline$H Y+C(1: 2)$ & $\mathrm{S}$ & $* * *$ & - & - & - \\
\hline$H Y+C(1: 3)$ & $\mathrm{T}$ & $* * *$ & - & - & - \\
\hline HY + C (1:4) & $\mathrm{T}$ & $* * *$ & - & - & - \\
\hline$H Y+C(1: 5)$ & - & $* * *$ & - & - & - \\
\hline$H Y+C+Q(1: 1: 1)$ & $\mathrm{S}$ & ** & * & - & - \\
\hline HY + C + Q (1:6:12) & - & $* *$ & * & - & - \\
\hline$H Y+Q(1: 1)$ & ** & - & * & - & - \\
\hline HY + Q (1:2) & * & - & ** & - & - \\
\hline$H Y+P(1: 1)$ & * & $\mathrm{T}$ ? & - & $* *$ & - \\
\hline$H Y+P(1: 2)$ & $\mathrm{S}$ & $\mathrm{T}$ ? & - & **** & - \\
\hline$H Y+P+Q(1: 6: 12)$ & - & $\mathrm{T}$ & $* *$ & * & - \\
\hline HY + MgO (1:1) & ** & - & - & - & $* * / *$ \\
\hline HY + MgO (1:2) & * & - & - & - & $* *$ \\
\hline HY + MgO (2:1) & $* *$ & - & - & - & * \\
\hline S : small amount $\left(5-20^{\circ}\right.$ & & $20-50 \%$ & & & \\
\hline $\mathrm{T}:$ traces $(<5 \%)$ & & $50-75 \%$ & & & \\
\hline - : undetectable & & $>75 \%$ & & & \\
\hline
\end{tabular}

Table 5. Simulated standards (weight ratios) and DTA results.

\begin{tabular}{|c|c|c|c|c|c|c|c|c|}
\hline \multirow[b]{2}{*}{$\begin{array}{l}\text { SIMULATED } \\
\text { STANDARDS }\end{array}$} & \multicolumn{7}{|c|}{$\mathrm{T}\left({ }^{\circ} \mathrm{C}\right)$} & \multirow[b]{2}{*}{$900^{\circ} \mathrm{C}$} \\
\hline & $320^{\circ} \mathrm{C}$ & $400^{\circ} \mathrm{C}$ & $440^{\circ} \mathrm{C}$ & $480^{\circ} \mathrm{C}$ & $510^{\circ} \mathrm{C}$ & $530^{\circ} \mathrm{C}$ & $573^{\circ} \mathrm{C}$ & \\
\hline pure HY & $\downarrow$ & - & $\downarrow$ & - & $\uparrow$ & $\downarrow$ & - & - \\
\hline HY + C (1:1) & $\downarrow$ & - & $\downarrow$ & - & $\uparrow$ & $\downarrow$ & - & $\downarrow$ \\
\hline$H Y+C(1: 2)$ & $\downarrow$ & - & $\downarrow$ & - & $\uparrow$ & $\downarrow$ & - & $\downarrow$ \\
\hline HY + C (1:3) & $\downarrow$ & - & $\downarrow$ & - & $\uparrow$ & $\downarrow$ & - & $\downarrow$ \\
\hline$H Y+C(1: 4)$ & $\downarrow$ & - & $\downarrow$ & - & $\uparrow$ & $\downarrow$ & - & $\downarrow$ \\
\hline$H Y+C(1: 5)$ & $\mathrm{s} \downarrow$ & - & $\mathrm{s} \downarrow$ & - & $\uparrow$ & $\downarrow$ & - & $\downarrow$ \\
\hline$H Y+C+Q(1: 1: 1)$ & $\downarrow$ & - & $\downarrow$ & - & $\uparrow$ & $\downarrow$ & $\downarrow$ & $\downarrow$ \\
\hline$H Y+C+Q(1: 6: 12)$ & $\mathrm{s} \downarrow$ & - & $\mathrm{s} \downarrow$ & - & $\uparrow$ & $\downarrow$ & $\downarrow$ & $\downarrow$ \\
\hline$H Y+Q(1: 1)$ & $\downarrow$ & - & $\downarrow$ & - & $\uparrow$ & $\downarrow$ & $\downarrow$ & - \\
\hline$H Y+Q(1: 2)$ & $\downarrow$ & - & $\downarrow$ & - & $\uparrow$ & $\downarrow$ & $\downarrow$ & - \\
\hline$H Y+P(1: 1)$ & $\downarrow$ & - & $\downarrow$ & $\downarrow$ & $\uparrow$ & $\downarrow$ & - & $\downarrow$ \\
\hline HY + P (1:2) & $\downarrow$ & - & $\downarrow$ & $\downarrow$ & $\uparrow$ & $\downarrow$ & - & $\downarrow$ \\
\hline$H Y+P+Q(1: 6: 12)$ & $\downarrow$ & - & $\downarrow$ & $\downarrow$ & $\uparrow$ & $\downarrow$ & $\downarrow$ & $\downarrow$ \\
\hline HY + MgO (1:1) & $\downarrow$ & $\downarrow$ & $\downarrow$ & - & $\uparrow$ & $\downarrow$ & - & - \\
\hline $\mathrm{HY}+\operatorname{MgO}(1: 2)$ & $\downarrow$ & $\downarrow$ & $\downarrow$ & - & $\uparrow$ & $\downarrow$ & - & - \\
\hline $\mathrm{HY}+\operatorname{MgO}(2: 1)$ & $\downarrow$ & $\downarrow$ & $\downarrow$ & - & $\uparrow$ & $\downarrow$ & - & - \\
\hline
\end{tabular}

$\downarrow$ : endothermic peak; $\downarrow \downarrow$ : slight endothermic peak; $\uparrow:$ exothermic peak; -: no peak 


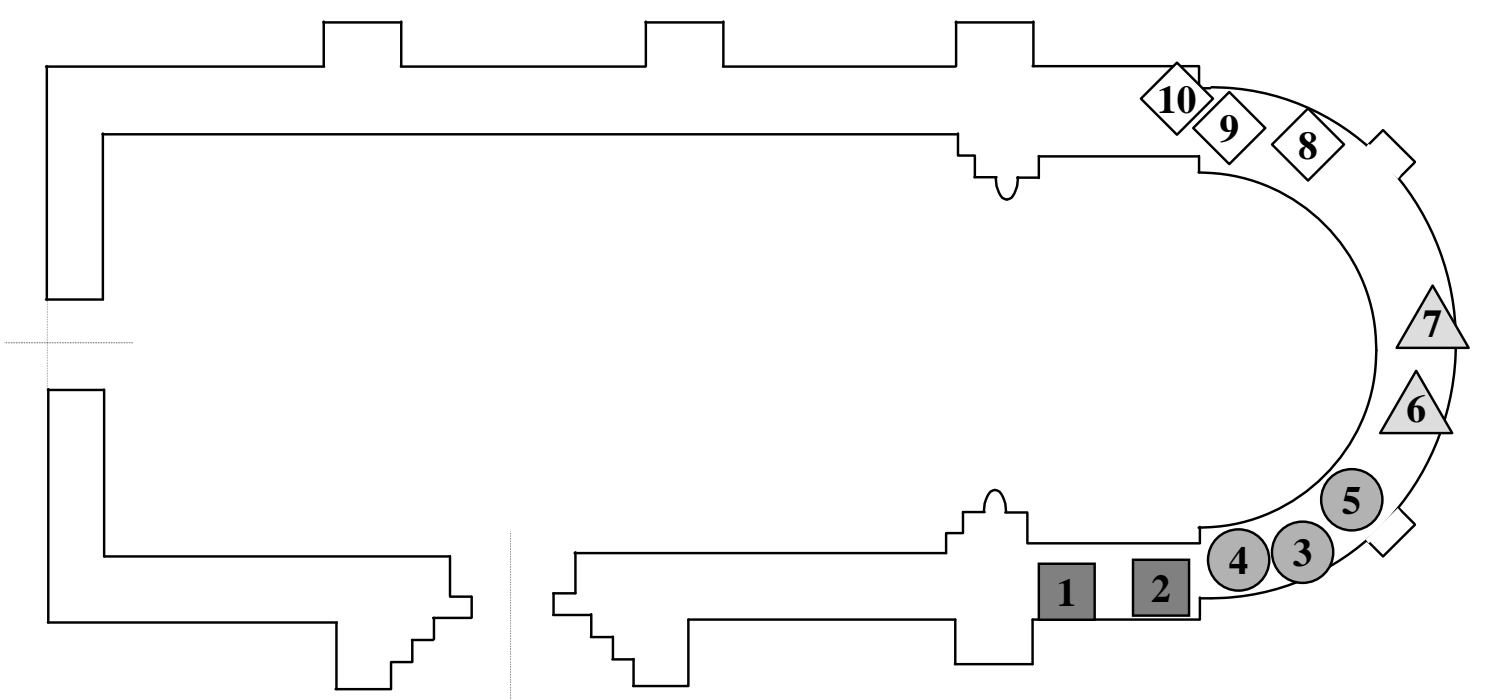

Figure 1. Plan of Santa María de Zamarce. Sampling areas.

\section{List of Legends:}

Figure 1. Plan of Santa María de Zamarce. Sampling areas.

Figure 2. (a) TG and DTG curves; (b) DTA curve from Z1 sample.

Figure 3. (a) TG and DTG curves; (b) DTA curve from Z5 sample.

Figure 4. X- ray diffraction patterns from hydromagnesite $(\mathrm{HY})+$ calcite $(\mathrm{C})$ prepared mixtures in their different weight ratios.

Figure 5. (a) TG and DTG curves; (b) DTA curve from pure hydromagnesite.

Figure 6. (a) TG and DTG curves; (b) DTA curve from $\mathrm{HY}+\mathrm{C}(1: 5)$ sample. 

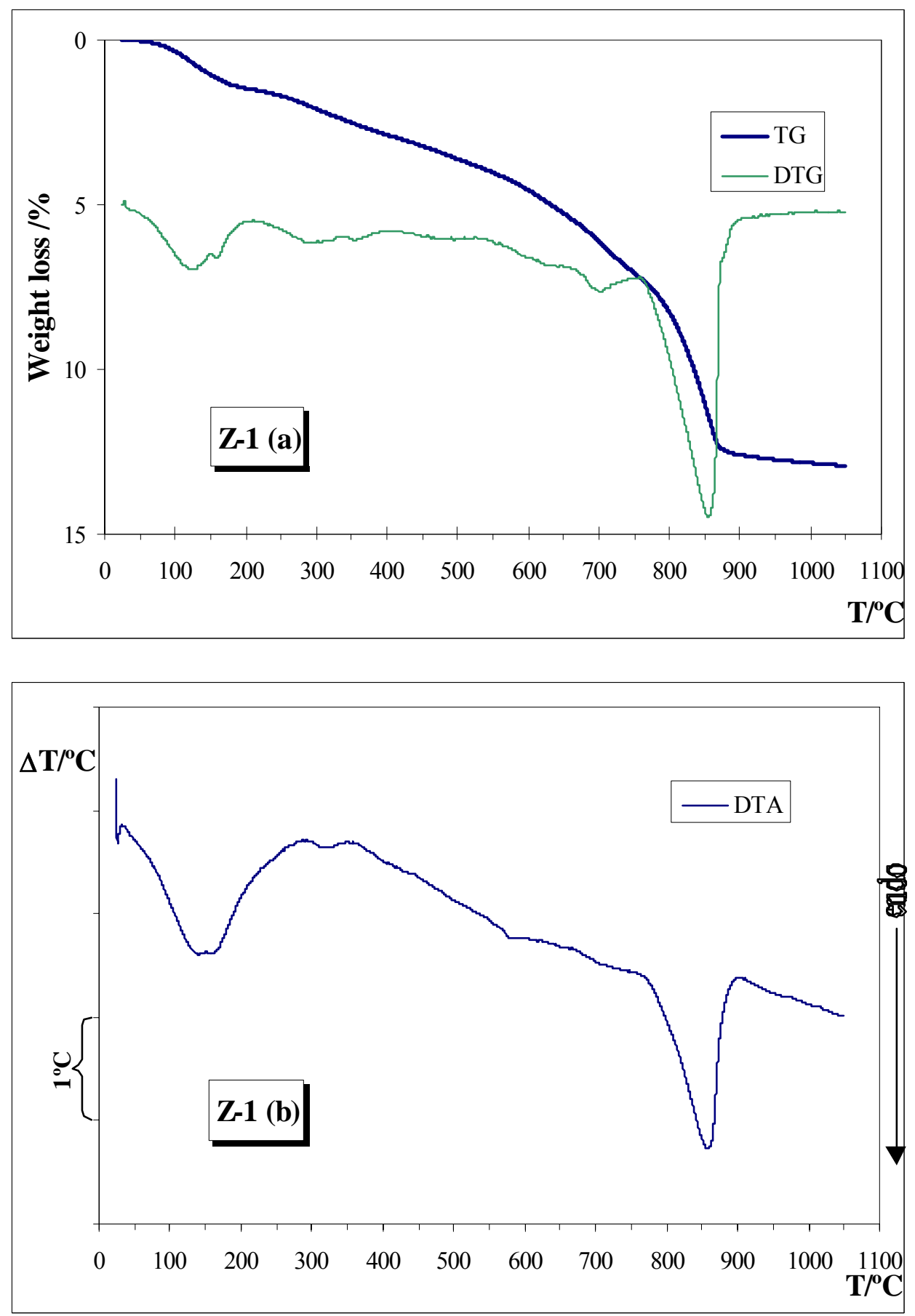

Figure 2. (a) TG and DTG curves; (b) DTA curve from Z1 sample. 

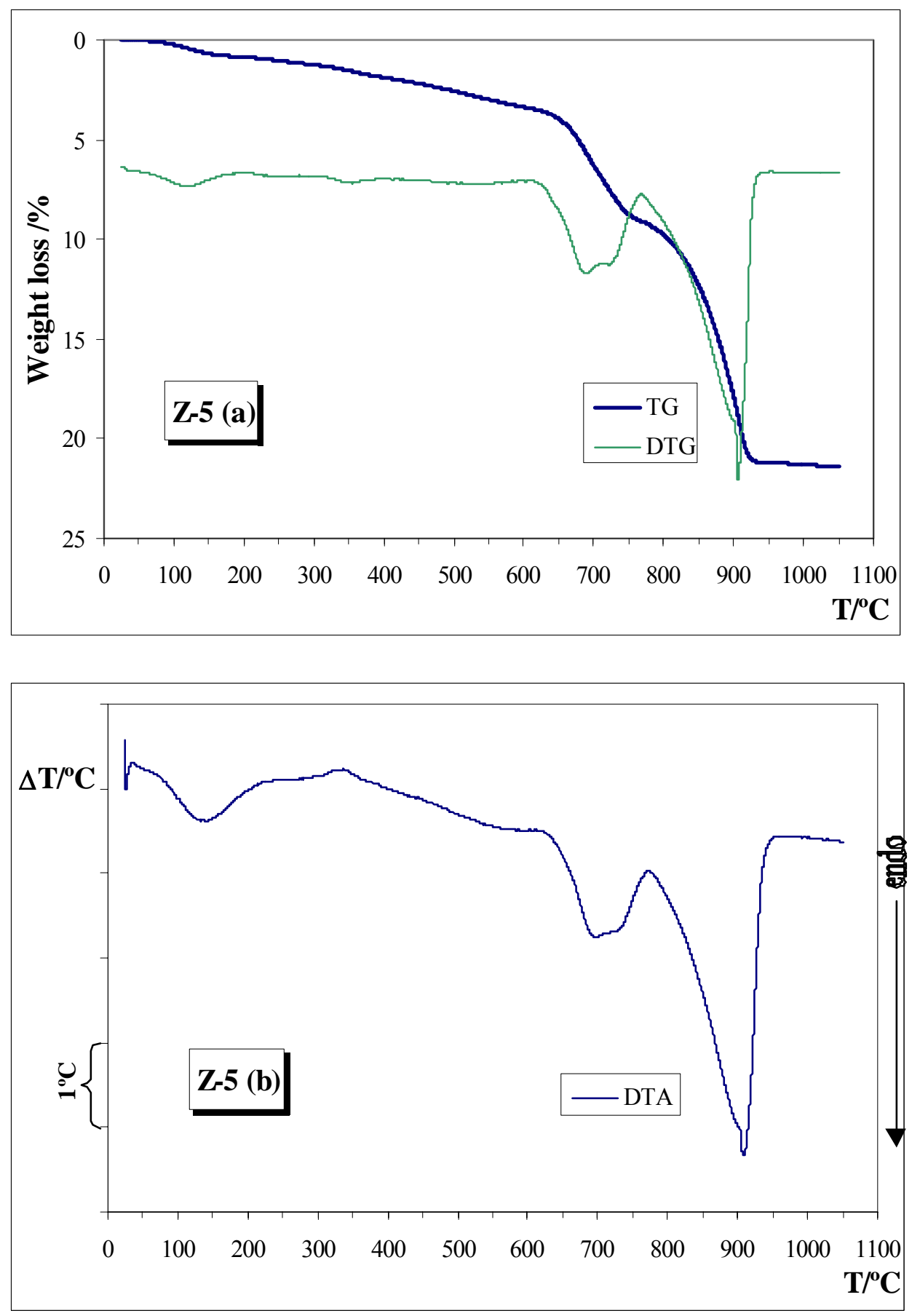

Figure 3. (a) TG and DTG curves; (b) DTA curve from Z5 sample. 


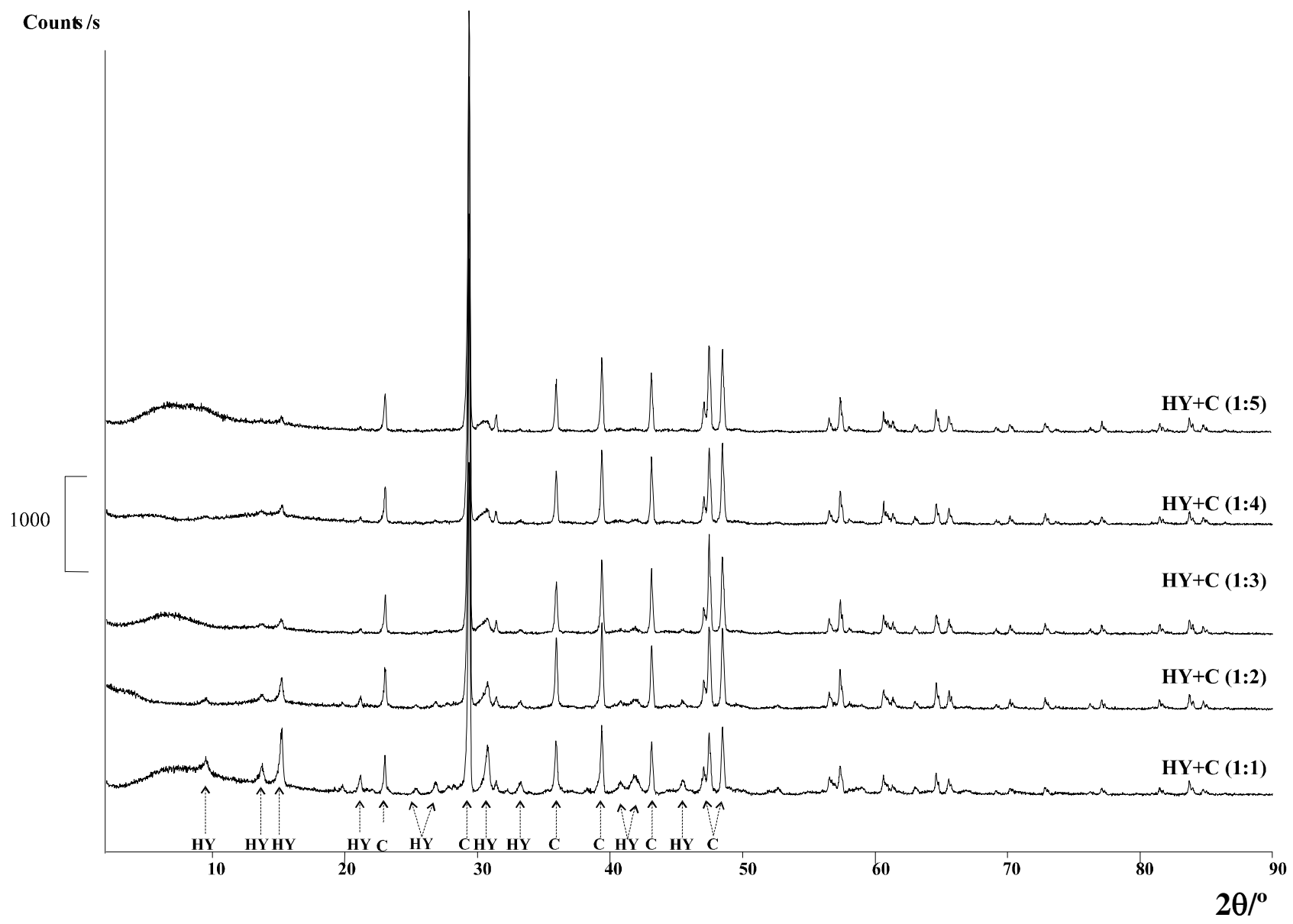

Figure 4. $\mathrm{X}$ - ray diffraction patterns from hydromagnesite $(\mathrm{HY})+$ calcite $(\mathrm{C})$ prepared mixtures in their different weight ratios. 

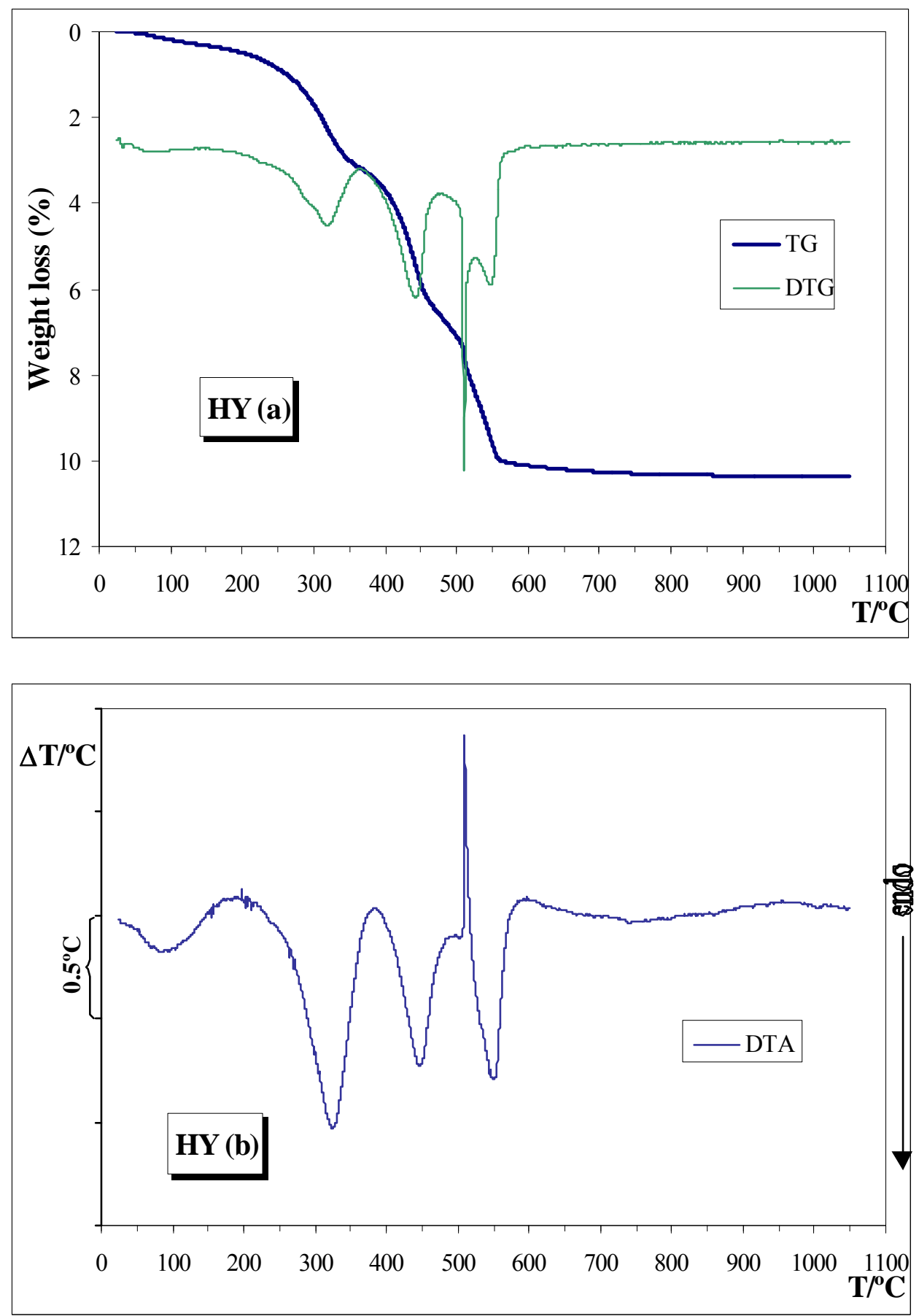

Figure 5. (a) TG and DTG curves; (b) DTA curve from pure hydromagnesite. 

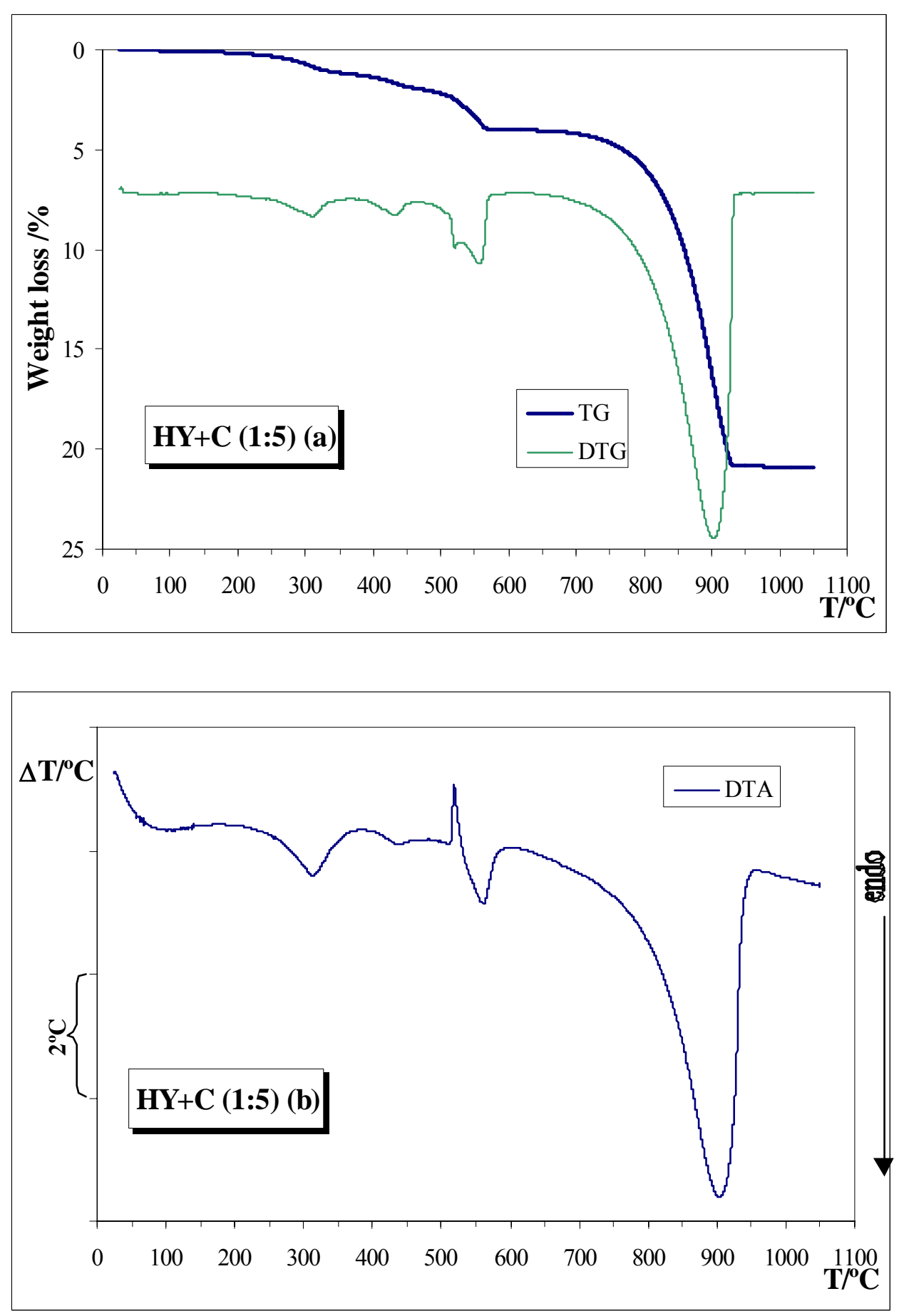

Figure 6. (a) TG and DTG curves; (b) DTA curve from HY+C (1:5) sample. 